\title{
PERSEPSI MAHASISWA TEKNIK TERHADAP PENGGUNAAN MEDIA ANIMASI FLASH DALAM PERKULIAHAN KIMIA DASAR
}

\author{
Eliyarti ${ }^{1}$, C. Rahayu ${ }^{2}$ \\ ${ }^{1,2}$ Program Studi Teknik Elektro \\ Universitas Ekasakti \\ Padang, Indonesia \\ e-mail: eliyarti58@gmail.com ${ }^{1}$, rahayuchichi@gmail.com $^{2}$
}

\begin{abstract}
Abstrak
Media pembelajaran merupakan penunjang kegiatan pengajaran agar efektif. Perkembangan teknologi yang semakin pesat saat ini mendorong banyak bermunculan aplikasi yang dapat digunakan sebagai media pembelajaran, salah satunya Macromedia Flash. Kenyataan di lapangan menunjukan ratarata nilai ujian akhir semester kimia dasar FT Unes secara klasikal masih rendah yaitu 65 dengan persentase mahasiswa yang lulus $42,85 \%$ dan yang tidak lulus $57,15 \%$. Sebagai solusi dari permasalahan tersebut maka dilakukan penelitian menggunakan media Flash sebagai media pembelajaran. Tujuan penelitian ini untuk mendeskripsikan persepsi mahasiswa teknik terhadap penggunaan media animasi flash dalam perkuliahan kimia dasar. Jenis penelitian ini deksriptif kuantitatif dengan sampel penelitian adalah mahasiswa tingkat I Fakultas Teknik dan Perencanaan Universitas Ekasakti dalam perkuliahan Kimia Dasar semester ganjil 2020/2021 berjumlah 80 orang yang dipilih dengan teknik simple random sampling. Teknik pengumpul data yang digunakan adalah teknik nontes berupa kuisioner. Berdasarkan hasil penelitian diperoleh bahwa mahasiswa teknik yang menyatakan setuju media animasi flash dapat mempercepat pemahaman materi kimia dasar sebanyak $56,25 \%$ sedangkan $43,75 \%$ tidak setuju, mahasiswa teknik yang menyatakan setuju media animasi flash dapat menuntun untuk memecahkan masalah berdasarkan konsep kimia dasar sebanyak 60\% sedangkan $40 \%$ tidak setuju, mahasiswa teknik yang menyatakan setuju media animasi flash menarik untuk digunakan dalam perkuliahan kimia dasar sebanyak $75 \%$ sedangkan $25 \%$ tidak setuju, mahasiswa teknik yang menyatakan setuju media animasi flash dapat memudahkan pemahaman konsep yang abstrak dalam perkuliahan kimia dasar sebanyak 68,75\% sedangkan 31,25\% tidak setuju, serta mahasiswa teknik yang menyatakan setuju media animasi flash dapat meningkatkan motivasi perkuliahan kimia dasar sebanyak $62,50 \%$ sedangkan $37,50 \%$ tidak setuju. Diharapkan penggunaan animasi flash dalam kegiatan pembelajaran semakin efektif kedepannya.
\end{abstract}

Kata kunci: Animasi Flash; Kimia Dasar; Media Pembelajaran

\section{Abstract}

Learning media is a support for teaching activities to be effective. The rapid development of technology today has prompted many applications to emerge that can be used as a learning media, one of which is Macromedia Flash. The reality in the field shows that the average score of basic chemistry final semester FT Unes classically is still low, namely 65 with the percentage of students who pass $42.85 \%$ and those who do not pass $57.15 \%$. As a solution to this problem, research was carried out using Macromedia Flash as a learning media. The purpose of this study was to describe the perceptions of engineering students towards the use of animation media in basic chemistry lectures. This type of research is descriptive quantitative with the research sample being students at level I of the Faculty of Engineering and Planning, Ekasakti University in the basic chemistry lectures in the odd semester of 2020/2021 totaling 80 people who were selected by simple random sampling technique. The data collection technique used was a non-test technique in the form of a questionnaire. Based on the research results, it was found that engineering students who agreed that flash animation media could accelerate understanding of basic chemistry by $56.25 \%$ while $43.75 \%$ disagreed, engineering students who agreed 
that flash animation media could lead to solving problems based on basic chemical concepts were $60 \%$ while $40 \%$ disagreed, engineering students who agreed that flash animation media was interesting to use in basic chemistry lectures were $75 \%$ while $25 \%$ disagreed, engineering students who agreed that flash animation media could facilitate understanding of abstract concepts in basic chemistry lectures were as much as $68.75 \%$ while $31.25 \%$ disagree, and engineering students who agree that flash animation media can increase motivation for basic chemistry lectures by $62.50 \%$ while $37.50 \%$ disagree. It is hoped that the use of flash animation in learning activities will be more effective in the future.

Keywords : Flash Animation; Basic Chemistry; Learning Media

\section{PENDAHULUAN}

Pendidikan memegang peranan penting dan strategis sebab merupakan sebuah wahana untuk meningkatkan kualitas sumber daya manusia (Zakirman, 2017). Tuntutan pendidikan yang sangat besar mendorong para akademisi untuk dapat berpartisipasi dalam berbagai perkembangan di dunia pendidikan (Putri, Ulhusna, Zakirman, \& Gusta, 2020). Tujuan utama pendidikan yaitu membuat perubahan dan mendidik peserta didik untuk meningkatkan kualitas hidup (Rahayu \& Eliyarti, 2019). Perubahan yang akan dilakukan dengan menambah wawasan dan pengetahuan sehingga memiliki kompetensi yang dapat digunakan di masa depan (Zakirman, Lufri, Khairani, \& Rahayu, 2020). Oleh karena itu, peningkatan kualitas pendidikan merupakan suatu keharusan bagi kemajuan bangsa, begitu pula dengan bangsa Indonesia (Putri et al., 2020).

Kualitas pendidikan dapat dibentuk melalui pembelajaran yang berkualitas, inovatif dan menyenangkan (Zakirman, 2019). Meningkatkan kualitas pembelajaran penting untuk dilakukan mulai dari pendidikan dasar dan menengah hingga pendidikan tinggi (Gusta, Christina, \& Zakirman, 2020). Kegiatan pembelajaran di perguruan tinggi melibatkan mahasiswa secara aktif untuk berinteraksi. Dosen harus mampu melaksanakan pembelajaran dengan berorientasi pada kegiatan mahasiswa dalam menemukan dan menetapkan makna secara mandiri sehingga proses pembelajaran akan dapat mengembangkan keterampilan berpikir tinggi (Zakirman \& Rahayu, 2018). Salah satu cara yang dapat ditempuh melalui penggunaan teknologi sebagai media pembelajaran (Castro \& Andrade, 2011).

Kata "Media" berasal dari bahasa latin yang merupakan bentuk jamak dari "medium", secara harfiah berarti perantara atau pengantar. Association for Education and Communication Technology (AECT), mengartikan kata media sebagai segala bentuk dan saluran yang dipergunakan untuk proses informasi. National Education Association (NEA) mendefinisikan media sebagai segala benda yang dapat dimanipulasikan, dilihat, didengar, dibaca atau dibicarakan beserta instrumen yang dipergunakan untuk kegiatan tersebut (Nurseto, 2011). Perlu dikemukakan pula bahwa kegiatan pembelajaran adalah suatu proses komunikasi. Dengan kata lain, kegiatan belajar melalui media terjadi bila ada komunikasi antar penerima pesan (P) dengan sumber (S) lewat media (M) tersebut. Namun proses komunikasi itu sendiri baru terjadi setelah ada reaksi balik (feedback) (Asrial et al., 2019). Dengan demikian media pembelajaran itu merupakan wahana penyalur pesan atau informasi belajar.

Penggunaan media dalam pembelajaran adalah untuk membantu proses belajar mengajar sehingga tujuan pengajaran dapat tercapai dengan efektif dan efisien (Eliyarti, Rahayu, \& Zakirman, 2020). Tujuan penggunaan media adalah untuk memberikan variasi proses pembelajaran, memberikan lebih banyak realitas dalam pembelajaran, sehingga lebih terwujut, lebih terarah untuk mencapai tujuan pembelajaran (Badlisyah \& Maghfirah, 2017). Selain itu, pemahaman 
konseptual mengacu pada kemampuan siswa untuk menghubungkan pengetahuan baru dengan pengetahuan yang ada dengan berbagai cara menyampaikannya tanpa mengubah makna sebenarnya. Oleh karena itu media diperlukan untuk menjelaskan materi secara lebih rinci, memvisualisasikan abstrak, memahami konsep dengan benar, melatih siswa berpikir dan mampu menyelesaikan masalah. Berdasarkan hal ini maka pemanfaatan teknologi sebagai media pembelajaran menjadi bagian yang tidak terpisahkan (Adawiyah \& Anwar, 2020).

Media pembelajaran berfungsi sebagai 1) memperjelas dan memperkaya/ melengkapi informasi yang diberikan secara verbal. 2) meningkatkan motivasi, efektivitas dan efesiensi penyampaian informasi. 3) menambah variasi penyajian materi. 4) dapat menimbulkan semangat, gairah, dan mencegah kebosanan siswa untuk belajar. 5) memudahkan materi untuk dicerna dan lebih membekas, sehingga tidak mudah dilupakan siswa. 6) memberikan pengalaman yang lebih konkret bagi hal yang mungkin abstrak. 7) memberikan stimulus dan mendorong respon siswa (O.I \& N.N.C, 2017)

Sebelum menggunakan media, guru harus memilih secara cermat. (Aksoy, 2012). Memilih media yang terbaik untuk tujuan pembelajaran bukanlah pekerjaan yang mudah. Pemilihan itu rumit dan sulit, karena harus mempertimbangkan berbagai faktor. Media pada hakekatnya merupakan salah satu komponen sistem pembelajaran. Sebagai komponen, media hendaknya merupakan bagian integral dan harus sesuai dengan proses pembelajaran secara menyeluruh. Akhir dari pemilihan media adalah penggunaaan media tersebut dalam kegiatan pembelajaran, sehingga memungkinkan siswa dapat berinteraksi dengan media yang guru pilih.

Apabila guru telah menentukan alternatif media yang akan kita gunakan dalam pembelajaran, maka pertanyaan berikutnya adalah sudah tersediakah media tersebut di sekolah? Jika sudah tersedia, maka guru tinggal meminjam atau membelinya saja. Itupun jika media yang ada memang sesuai dengan tujuan pembelajaran yang telah guru rencanakan, dan terjangkau harganya. Jika media yang kita butuhkan temyata belum tersedia, mau tak mau kita harus membuat sendiri program media sesuai keperluan tersebut (Astiningsih \& Partana, 2020).

Untuk itu, pemilihan jenis media harus dilakukan dengan prosedur yang benar, karena begitu banyak jenis media dengan berbagai kelebihan dan kelemahan masing masing. Secara umum kriteria yang harus dipertimbangkan dalam pemilihan media pembelajaran diuraikan sebagai berikut :

1. Tujuan. Apa tujuan pembelajaran (standar kompetensi dan kompetensi dasar) yang ingin dicapai? Apakah tujuan itu masuk ranah kognitif, afektif, psikomotor, atau kombinasinya? Jenis rangsangan indera apa yang ditekankan: apakah penglihatan, pendengaran, atau kombinasinya? Jika visual, apakah perlu gerakan atau cukup visual diam? Jawaban atas pertanyaan itu akan mengarahkan kita pada jenis media tertentu, apakah media realia, audio, visual diam, visual gerak, audio visual gerak dan seterusnya.

2. Sasaran didik. Siapakah sasaran didik yang akan menggunakan media? bagaimana karakteristik mereka, berapa jumlahnya, bagaimana latar belakang sosialnya, bagaimana motivasi dan minat belajarnya? dan seterusnya. Apabila kita mengabaikan kriteria ini, maka media yang kita pilih atau kita buat tentu tak akan banyak gunanya. Mengapa? Karena pada akhirnya sasaran inilah yang akan mengambil manfaat dari media pilihan kita itu. Oleh karena itu, media harus sesuai benar dengan kondisi mereka.

3. Karakteristik media yang bersangkutan. Bagaimana karakteristik media tersebut? Apa kelebihan dan kelemahannya, sesuaikah media yang 
akan kita pilih itu dengan tujuan yang akan dicapai? Kita tidak akan dapat memilih media dengan baik jika kita tidak mengenal dengan baik karakteristik masing masing media. Karena kegiatan memilih pada dasamya adalah kegiatan membandingkan satu sama lain, mana yang lebih baik dan lebih sesuai dibanding yang lain. Oleh karena itu, sebelum menentukan jenis media tertentu, pahami dengan baik bagaimana karaktristik media tersebut.

4. Waktu. Yang dimaksud waktu di sini adalah berapa lama waktu yang diperlukan untuk mengadakan atau membuat media yang akan kita pilih, serta berapa lama waktu yang tersedia/yang kita memiliki, cukupkah? Pertanyaan lain adalah, berapa lama waktu yang diperlukan untuk menyajikan media tersebut dan berapa lama alokasi waktu yang tersedia dalam proses pembelajaran? Tak ada gunanya kita memilih media yang baik, tetapi kita tidak cukup waktu untuk mengadakannya. Jangan sampai pula terjadi, media yang telah kita buat dengan menyita banyak waktu, tetapi pada saat digunakan dalam pembelajaran temyata kita kekurangan waktu.

5. Biaya. Faktor biaya juga merupakan pertanyaan penentu dalam menyewa media tersebut? Bisakah kita mengusahakan biaya tersebut/apakah besarnya biaya seimbang dengan tujuan belajar yang hendak dicapai? Tidak mungkinkah tujuan belajar itu tetap dapat dicapai tanpa memilih media. Bukankah penggunaan media pada dasarnya dimaksudkan untuk meningkatkan efisiensi dan efektivitas pembelajaran. Apalah artinya kita menggunakan media, jika akibatnya justru pemborosan. Oleh sebab itu, faktor biaya menjadi kriteria yang harus kita pertimbangkan. Berapa biaya yang kita perlukan untuk membuat, membeli atau menggunakan media itu, adakah alternatif media lain yang lebih murah namun tetap dapat mencapai tujuan belajar? Media yang mahal belum tentu lebih efektif untuk mencapai tujuan belajar dibandingkan media sederhana dan murah.

6. Ketersediaan. Kemudahan dalam memperoleh media juga menjadi pertimbangan kita. Adakah media yang kita butuhkan itu di sekitar kita, di sekolah atau di pasaran? Kalau kita harus membuatnya sendiri, adakah kemampuan, waktu tenaga dan sarana untuk membuatnya? Kalau semua itu ada, pertanyaan berikutnya adalah tersediakah sarana yang diperlukan untuk menyajikannya di kelas? Misalnya, untuk menjelaskan tentang proses terjadinya gerhana matahari memang lebih efektif disajikan melalui media video. Namun karena di sekolah tidak ada video player, maka sudah cukup bila digunakan alat peraga gerhana matahari.

7. Konteks Penggunaan. Konteks penggunaan maksudnya adalah dalam kondisi dan strategi bagaimana media tersebut akan digunakan. Misalnya: apakah untuk belajar individual, kelompok kecil, kelompok besar atau masal? Dalam hal ini kita perlu merencanakan strategi pembelajaran secara keseluruhan yang akan kita gunakan dalam proses pembelajaran, sehingga tergambar kapan dan bagaimana konteks penggunaaan media tersebut dalam pembelajaran.

8. Mutu teknis. Kriteria ini terutama untuk memilih/membeli media siap pakai yang telah ada, misalnya program audio, video, grafis atau media cetak lain. Mutu teknis media tersebut, visual jelas, menarik, dan cocok; suaranya jelas dan enak didengar, jangan sampai hanya karena keinginan kita untuk menggunakan media saja, lantas media yang kurang bermutu kita paksakan penggunaannya. (Zulfiani, Suwarna, \& Miranto, 2010) 
Kelebihan media animasi adalah penggabungan unsur media lain seperti audio, teks, video, image, grafik, dan sound menjadi satu kesatuan penyajian, sehingga mengakomodasi sesuai dengan modalitas belajar siswa. Selain itu, dapat mengakomodasi siswa yang memiliki tipe visual, auditif, mupun kinestetik (Sugiharti \& Ananda, 2021).

Ada beberapa faktor yang mempengaruhi seorang guru dalam memilih dan menggunakan media dalam menyampaikan informasi, fikiran dan pesan kepada anak didiknya, diantaranya: 1) Media mempermudah orang menyampaikan dan menerima materi, fikiran dan pesan serta dapat menghindarkan salah pengertian, 2) Media mendorong keinginan seseorang untuk mengetahui lebih lanjut informasi yang sedang dipelajarinya, 3) Media dapat mengekalkan pengertian yang didapat, 4) Media sudah berkembang di masyarakat Singthongchai, \& Naenudorn, 2012).

Media animasi Flash merupakan sebuah program yang mampu membuat animasi mulai dari yang sederhana hingga kompleks (Hartiti, 2013). Selain itu, pengguna dapat berkreasi dengan mudah dan bebas untuk membuat animasi dengan gerakan yang luwes sesuai alur atau kronologi adegan animasi yang diinginkan. Dengan keleluasaan ini pengguna dapat merancang animasi yang bahkan tidak terbatas (Satriaji, 2018). Sebagai contoh jika suatu percobaan membutuhkan waktu terlalu lama atau terlalu mahal. Pada saat seperti inilah diperlukan alat bantu pengajaran, salah satunya adalah pembelajaran menggunakan animasi flash (Asmawati \& Dalming, 2019).

Keunikan penggunaan media macromedia flash dimana pengenalan materi dapat dibuat berupa dua dimensi berwarna-warni dengan disertai gerakan dan keterangan. Hal ini akan memeperjelas materi yang bersifat abstrak sehingga membuat siswa tidak merasa bosan, selain itu disertai audio yang akan memperjelas materi serta konsep yang ditampilkan. Dengan animasi membantu siswa untuk lebih memahami proses molekuler dinamis dalam bidang kimia. Media animasi memilki keterkaitan dengan animasi game yang sekarang populer dikalangan anak-anak, sehingga siswa akan lebih tertarik dan mudah menerima konsep (Gusbandono, Sukadrjo, \& Utomo, 2013)

Beberapa kelebihan media animasi flash adalah : 1). Hasil akhir file memiliki ukuran yang lebih kecil. 2). Animasi flash mampu mengimpor hampir semua file gambar dan file-file audio sehingga presentasi dengan animasi flash lebih hidup. 3). Animasi dapat dibentuk, dijalankan dan dikontrol. 4). Animasi flash mampu membuat file executable * ${ }^{*}$.Exe) sehingga dapat dijalankan pada Pc manapun tanpa harus menginstal terlebih dahulu program flash. 5). Font persentasi tidak akan berubah meskipun PC yang digunakan tidak memiliki font tersebut. 6). Gambar macromedia flash merupakan gambar vector sehingga tidak akan pecah apabila di zoom (Manurung, 2021)

Kimia merupakan ilmu yang mempelajari mengenai komposisi, struktur, dan sifat zat atau materi dari skala atom (mikroskopik) hingga molekul serta perubahan atau transformasi serta interaksi mereka untuk membentuk materi yang ditemukan sehari-hari (Eliyarti \& Rahayu, 2019a). IImu kimia banyak memberikan pengaruh dalam pengembangan ilmu dan teknologi. Hal ini membuktikan bahwa ilmu kimia sangat erat kaitannya dengan kehidupan. Konsep-konsep kimia erat kaitannya dengan kehidupan sehari-hari karena apapun yang ada pada kehidupan kita semuanya berhubungan dengan kimia (Badlisyah \& Maghfirah, 2017).

Kimia sebagai bagian dari ilmu sains juga dipenuhi dengan konsep abstrak dan memerlukan alat bantu untuk memvisualisasikannya saat mengajar (Ezeano \& Ezeudu, 2013). Animasi flash yang menjadi media pembelajaran, bukan hanya sekedar alat bantu belaka melainkan 
sebagai media penyalur pesan dalam bentuk visual maupun audio dari pengajar ke peserta didik. Animasi flash merupakan program aplikasi yang mempunyai fasilitas terdiri atas teks, gambar, simulasi, animasi, video, audio, atau efek-efek khusus lainnya sehingga dapat menyalurkan pesan media pembelajaran yang dapat menyampaikan informasi secara lebih teliti, jelas, dan menarik (Nurdin, Sulastry, \& Hasri, 2018)

Peran teknologi sebagai alat bantu dalam pembelajaran dibutuhkan khususnya untuk mengembangkan kreativitas dosen kimia, inovasi dalam pembelajaran, mendorong minat mahasiswa untuk tertarik dengan ilmu kimia, dan membawa konsepkonsep yang abstrak ke dunia lebih nyata agar lebih komunikatif dan inovatif dalam proses pembelajarannya. Berbagai perangkat komputer beserta koneksinya dapat menghantarkan peserta belajar secara cepat dan akurat apabila dimanfaatkan secara benar dan tepat (Epinur \& Yusnidar, 2015). Dalam konten ini, animasi flash dapat meningkatkan potensi belajar dengan memungkinkan siswa mengekspresikan pengalaman mereka dengan mudah (Sumarni, Sudarmin, \& Kadarwati, 2013). Animasi flash sebagai media pembelajaran kimia dasar dapat membantu mengintegrasikan teks, gambar, serta suara dan video secara bersamaan, sehingga pembelajaran akan terasa menarik, efektif serta efisien (Haryani \& Edi, 2019).

Penggunaan media pembelajaran animasi flash ini sudah tidak asing lagi dalam pembelajaran kimia pada berbagai materi/pokok bahasan. Penelitian terdahulu yang dilakukan Asmawati dan Dalming (2019) diperoleh bahwa media animasi flash pada materi asam-basa menunjukkan $82 \%$ dari 23 siswa sudah tuntas, 96\% siswa memberikan respon positif dan tanggapan guru terhadap media masuk kategori baik (Asmawati \& Dalming, 2019). Penelitian yang dilakukan oleh Christianti, dkk (2012) menunjukkan bahwa respon siswa terhadap pembelajaran koloid berbasis animasi flash adalah sangat baik karena suasana pembelajaran menjadi lebih menyenangkan dan menarik bagi siswa, sehingga mereka lebih optimal dalam memahami materi pelajaran (Christianti \& Subroto, 2012). Hasil penelitian lainnya, respon siswa terhadap pembelajaran kimia menggunakan media animasi flash menunjukkan hasil yang positif sebesar $69,2 \%$ dan respon netral sebesar 30,8\% tanpa ada yang respon negatif (Wiwit \& Putra, 2012).

Berikutnya, peningkatan minat belajar kimia siswa melalui pemanfaatan media pembelajaran animasi flash persentasi minat belajar siswa pada materi ikatan kimia meningkat adalah sebesar $18 \%$ (Sormin \& Daeli, 2018). Penelitian lainnya menunjukan penggunaan animasi flash pada kelas eksperimen memiliki peningkatan hasil belajar sebesar 57\%, sedangkan peningkatan hasil belajar mahasiswa pada kelas kontrol hanya sebesar 39\% yaitu sekitar 2/3 dari peningkatan hasil belajar kelas eksperimen (Febliza \& Afdal, 2019).

Mata kuliah Kimia Dasar di Fakultas Teknik Unes memuat materi; 1) Stoikiometri, 2) Energetika, 3) Struktur Atom, 4) Struktur Molekul, 5) Sistem Periodik, 6) Wujud Zat, 7) Kesetimbangan Kimia, 8) Konsep Kimia Larutan, 9) Sistem Koloid, 10) Kinematika Kimia, 11) Kimia Unsur, 12) Kimia Inti dan radio kimia, dan 13) hidrokarbon. Selain perkuliahan di kelas juga terdapat kegiatan praktikum di laboratorium. Namun, tidak semua materi ini dapat dipraktikumkan karena konsepnya bersifat abstrak serta kekurangan alat dan bahan praktikum. Kenyataan di lapangan menunjukan ratarata nilai ujian akhir semester kimia dasar FT Unes secara klasikal masih rendah yaitu 65 dengan persentase mahasiswa yang lulus $42,85 \%$ dan yang tidak lulus $57,15 \%$. Sebagai solusi dari permasalahan tersebut maka dilakukan penelitian menggunakan media flash sebagai media pembelajaran dalam perkuliahan Kimia Dasar. Dengan demikian tujuan penelitian ini untuk mendeskripsikan persepsi mahasiswa 
teknik terhadap penggunaan media animasi dalam perkuliahan kimia dasar.

\section{METODE}

Jenis penelitian ini adalah deksriptif kuantitatif yang bertujuan untuk mendeskripsikan persepsi mahasiswa teknik terhadap penggunaan media animasi dalam perkuliahan kimia dasar. Media animasi yang digunakan adalah macromedia Flash 8. Sampel penelitian ini adalah mahasiswa tingkat I Fakultas Teknik dan Perencanaan Universitas Ekasakti dalam perkuliahan Kimia Dasar semester ganjil 2020/2021 berjumlah 80 orang yang dipilih dengan teknik simple random sampling. Teknik pengumpul data yang digunakan adalah teknik nontes berupa kuisioner. Kuisioner digunakan untuk memperoeh data respon mahasiswa terhadap penggunaan media animasi dalam perkuliahan kimia.

Prosedur penelitian yang dilakukan adalah: (1) penyusunan kuisioner, (2) penyebaran kuisioner (3) analisa kuisioner, (4) menarik kesimpulan. Kuisioner yang disebarkan berisi 5 item pertanyaan yang masing-masingnya dibutuhkan respon berupa ceklis ataupun uraian pada setiap kolom jawaban item sesuai dengan pendapat responden. Sebelum melakukan penyebaran kuisioner perlu dilakukan terlebih dahulu penilaian terhadap kuisioner yang akan digunakan untuk menvalidasi kuisioner tersebut. Pada kegiatan ini, validator diminta untuk menilai kuisioner yang sudah dibuat. Selanjutnya dilakukan penyebaran kuisioner. Ringkasan poin pertanyaan pada kuisioner yang digunakan dalam penelitian ini disajikan pada tabel 1 berikut ini:

Tabel 1. Item Pertanyaan Instrumen

\begin{tabular}{ll}
\hline No & \multicolumn{1}{c}{ Fokus Pertanyaan } \\
\hline 1 & $\begin{array}{l}\text { Media animasi flash dapatkah } \\
\text { mempercepat pemahaman materi }\end{array}$ \\
& $\begin{array}{l}\text { kimia dasar } \\
\text { Media animasi flash dapatkah } \\
\text { menuntun untuk memecahkan }\end{array}$ \\
\hline
\end{tabular}

\begin{tabular}{ll}
\hline No & \multicolumn{1}{c}{ Fokus Pertanyaan } \\
\hline & $\begin{array}{l}\text { masalah berdasarkan konsep kimia } \\
\text { dasar }\end{array}$ \\
3 & $\begin{array}{l}\text { Media animasi flash apakah } \\
\text { menarik untuk digunakan dalam } \\
\text { perkuliahan kimia dasar }\end{array}$ \\
4 & $\begin{array}{l}\text { Media animasi flash dapatkah } \\
\text { memudahkan pemahaman konsep } \\
\text { yang abstrak dalam perkuliahan } \\
\text { kimia dasar }\end{array}$ \\
& $\begin{array}{l}\text { Media animasi flash dapatkah } \\
\text { meningkatkan motivasi perkuliahan } \\
\text { kimia dasar }\end{array}$ \\
\hline
\end{tabular}

Selanjutnya data respon mahasiswa akan diklasifikasi berdasarkan perolehan persentase sesuai dengan Tabel 2 berikut.

\begin{tabular}{|c|c|c|}
\hline No & $\begin{array}{l}\text { Perolehan } \\
\text { persentase }\end{array}$ & Keterangan \\
\hline 1 & $86 \leq N \leq 100$ & Sangat baik \\
\hline 2 & $76 \leq N \leq 85$ & Baik \\
\hline 3 & $60 \leq N \leq 75$ & Cukup \\
\hline 4 & $55 \leq N \leq 59$ & Kurang \\
\hline 5 & $0 \leq N \leq 54$ & Kurang sekali \\
\hline
\end{tabular}

\section{HASIL DAN PEMBAHASAN}

saat Media animasi flash digunakan pada mendemonstrasikan fenomena kimia dalam perkuliahan selama satu semester. Selanjutnya kuisioner diberikan menjelang akhir semester untuk mengetahui persepsi mahasiswa terhadap penggunaan media animasi flash tersebut. Data yang diperoleh dari penelitian ini adalah hasil analisis kuisioner yang diisi oleh 80 orang responden. Analisis dilakukan untuk setiap item pertanyaan yang terdapat pada kuisioner. Selanjutnya hasil analisis berupa persentase disajikan dalam bentuk diagram.

Berikut pemaparan hasil analisa kuisioner per item pertanyaan:

Pertanyaan 1: dapatkah media animasi Flash mempercepat pemahaman materi kimia dasar?. Hasil analisis kuisioner untuk 
pertanyaan ini dapat dilihat pada Gambar 1 berikut.

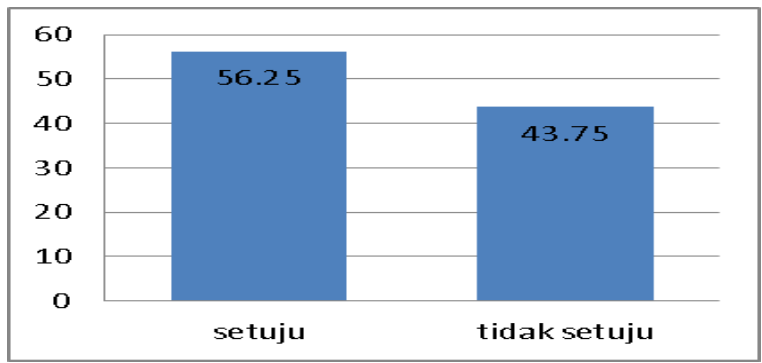

Gambar 1. Hasil analisis item pertanyaan 1

Berdasarkan hasil analisis item pertanyaan 1 diketahui bahwa mahasiswa teknik yang menyatakan setuju media animasi flash dapat mempercepat pemahaman materi kimia dasar sebanyak 45 orang atau sekitar $56,25 \%$ sedangkan yang tidak setuju 35 orang atau sekitar 43,75\%.

Pertanyaan 2: dapatkah media animasi flash menuntun untuk memecahkan masalah berdasarkan konsep kimia dasar?. Hasil analisis kuisioner untuk pertanyaan ini dapat dilihat pada Gambar 2 berikut.

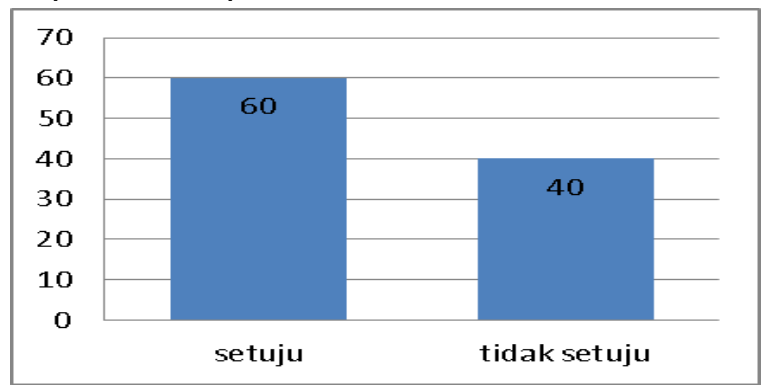

Gambar 2. Hasil analisis item pertanyaan 2

Berdasarkan hasil analisis item pertanyaan 2 diketahui bahwa mahasiswa teknik yang menyatakan setuju media animasi flash dapat menuntun untuk memecahkan masalah berdasarkan konsep kimia dasar sebanyak 48 orang atau sekitar $60 \%$ sedangkan yang tidak setuju 32 orang atau sekitar $40 \%$.

Pertanyaan 3: apakah media animasi flash menarik untuk digunakan dalam perkuliahan kimia dasar?. Hasil analisis kuisioner untuk pertanyaan ini dapat dilihat pada Gambar 3 berikut.

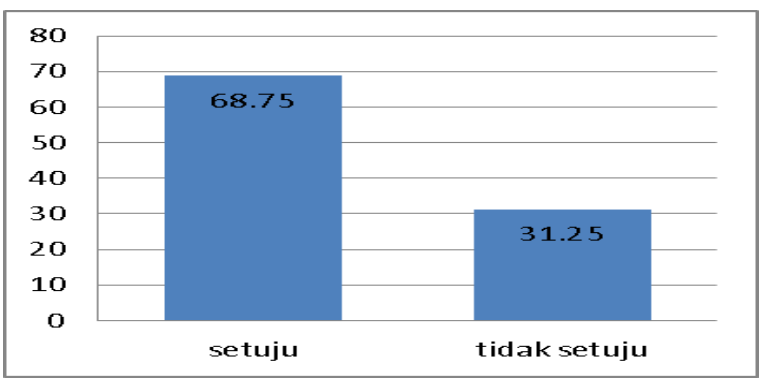

Gambar 3. Hasil analisis item pertanyaan 3

Berdasarkan hasil analisis item pertanyaan 3 diketahui bahwa mahasiswa teknik yang menyatakan setuju media animasi flash menarik untuk digunakan dalam perkuliahan kimia dasar sebanyak 60 orang atau sekitar $75 \%$ sedangkan yang tidak setuju 20 orang atau sekitar $25 \%$.

Pertanyaan 4: dapatkah media animasi flash memudahkan pemahaman konsep yang abstrak dalam perkuliahan kimia dasar?. Hasil analisis kuisioner untuk pertanyaan ini dapat dilihat pada Gambar 4 berikut.

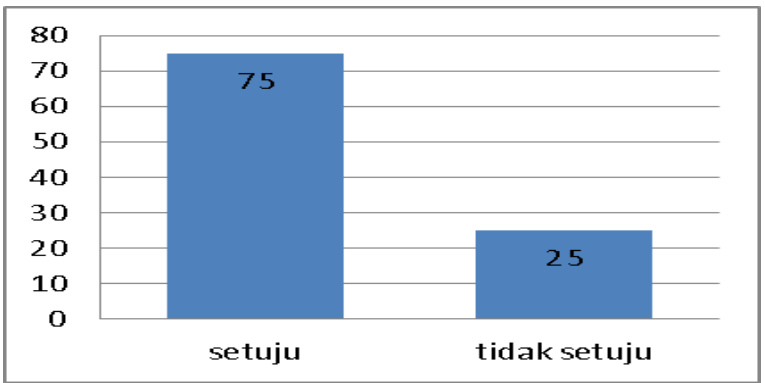

Gambar 4. Hasil analisis item pertanyaan 4

Berdasarkan hasil analisis item pertanyaan 4 diketahui bahwa mahasiswa teknik yang menyatakan setuju media animasi flash dapat memudahkan pemahaman konsep yang abstrak dalam perkuliahan kimia dasar sebanyak 55 orang atau sekitar $68,75 \%$ sedangkan yang tidak setuju 25 orang atau sekitar 31,25\%.

Pertanyaan 5: dapatkah media animasi flash meningkatkan motivasi perkuliahan kimia dasar?. Hasil analisis kuisioner untuk pertanyaan ini dapat dilihat pada Gambar 5 berikut. 
Diterima : 03-09-2021 | Disetujui : 28-09-2021| Diterbitkan : 06-10-2021

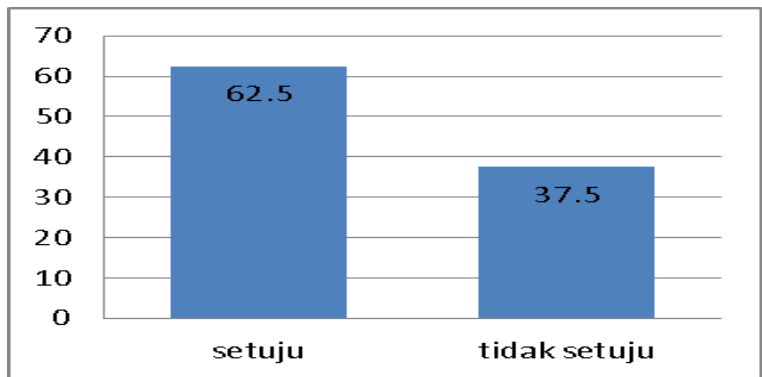

Gambar 5. Hasil analisis item pertanyaan 5

Berdasarkan hasil analisis item pertanyaan 5 diketahui bahwa mahasiswa teknik yang menyatakan setuju media animasi flash dapat meningkatkan motivasi perkuliahan kimia dasar sebanyak 50 orang atau sekitar $62,50 \%$ sedangkan yang tidak setuju 30 orang atau sekitar $37,50 \%$.

Secara umum hasil analisis persepsi mahasiswa terhadap penggunaan media animasi Flash dapat disajikan dalam bentuk diagram seperti dibawah ini.

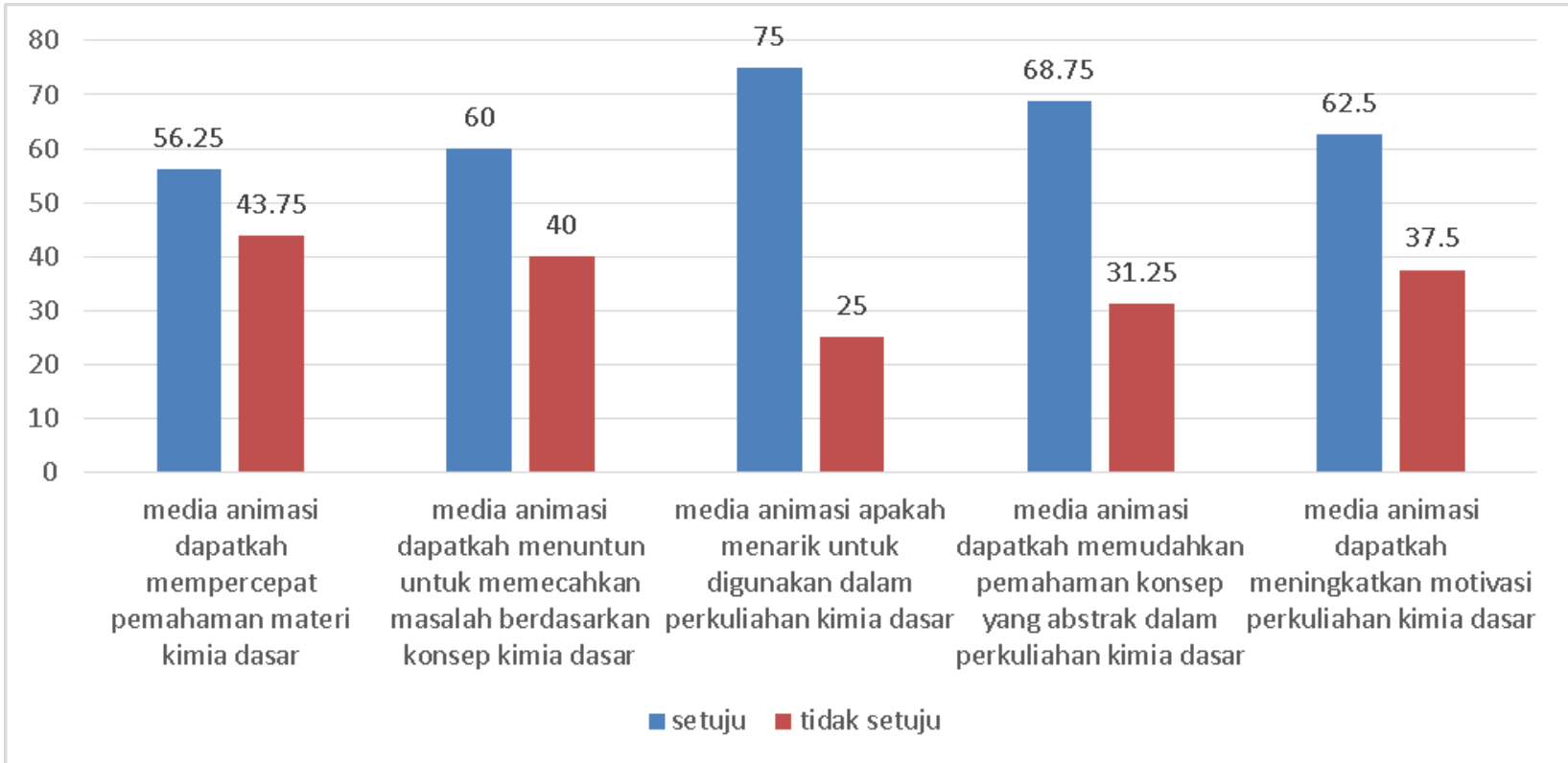

Gambar 6 Hasil analsis persepsi mahasiswa terhadap penggunaan media animasi Flash dalam perkuliahan Kimia Dasar

Berdasarkan Gambar 6 dapat dipahami bahwa mahasiswa yang memberikan respon positif terhadap penggunaan media animasi flash lebih banyak daripada yang memberikan respon negatif. Hal ini menunjukan penggunaan animasi Flash dalam perkuliahan kimia dasar mendapat respon positif.

$$
\text { Mahasiswa yang mengikuti }
$$
perkuliahan menjadi lebih termotivasi. Motivasi menjadi proses yang menjelaskan intensitas, arah dan ketekunan seseorang individu untuk mencapai tujuannya. Dengan adanya motivasi akan meningkatkan pengoptimalan aktivitas berpikir sehingga dapat meningkatkan kompetensi diri (Eliyarti \& Rahayu, 2019b). Penggunaan animasi
Flash memudahkan mahasiswa dalam memahami fenomena kimia yang disajikan seperti yang dinyatakan oleh Christianti (2012). Dalam penelitian ini sebagai contoh pada materi larutan elektrolit dan non elektrolit, dimana mahasiswa dapat menyaksikan animasi alat uji elektrolit sehingga mereka dapat mengetahui larutan mana yang memiliki daya hantar listrik.

Peningkatan minat belajar kimia juga terlihat diantaranya; mahasiswa menunjukan sikap lebih antusias dalam perkuliahan, dalam kegiatan tanya jawab diakhir perkuliahan mahasiswa memberikan tanggapan yang lebih baik, aktif menjawab pertanyaan, dan memberikan jawaban. Hal ini sesuai dengan pernyataan Elferida 
Humanities Research, 513, 78-84.

(2018) bahwa media animasi flash mampu meningtkan minat belajar kimia siswa. Dengan demikian pengajaran menjadi efektif. Pengajaran efektif adalah pengajaran yang dapat memberikan dampak yang lebih besar kepada mahasiswa dalam arti mudah dipahami, lebih lama diingat, lebih disenangi dan termotivasi untuk dipelajari (Badlisyah \& Maghfirah, 2017).

\section{PENUTUP}

Berdasarkan hasil analisis data diperoleh hasil sebagai berikut: (1) mahasiswa teknik yang menyatakan setuju media animasi flash dapat mempercepat pemahaman materi kimia dasar sebanyak 45 orang atau sekitar $56,25 \%$ sedangkan yang tidak setuju 35 orang atau sekitar $43,75 \%$, (2) mahasiswa teknik yang menyatakan setuju media animasi flash dapat menuntun untuk memecahkan masalah berdasarkan konsep kimia dasar sebanyak 48 orang atau sekitar 60\% sedangkan yang tidak setuju 32 orang atau sekitar 40\%, (3) mahasiswa teknik yang menyatakan setuju media animasi flash menarik untuk digunakan dalam perkuliahan kimia dasar sebanyak 60 orang atau sekitar $75 \%$ sedangkan yang tidak setuju 20 orang atau sekitar 25\%, (4) mahasiswa teknik yang menyatakan setuju media animasi flash dapat memudahkan pemahaman konsep yang abstrak dalam perkuliahan kimia dasar sebanyak 55 orang atau sekitar $68,75 \%$ sedangkan yang tidak setuju 25 orang atau sekitar $31,25 \%$, (5) mahasiswa teknik yang menyatakan setuju media animasi flash dapat meningkatkan motivasi perkuliahan kimia dasar sebanyak 50 orang atau sekitar $62,50 \%$ sedangkan yang tidak setuju 30 orang atau sekitar $37,50 \%$.

\section{DAFTAR PUSTAKA}

Adawiyah, R., \& Anwar, L. (2020). Implementation of an Interactive EModule to Improve Concept Understanding of Students. Advances in Social Science, Education and
Aksoy, G. (2012). The Effects of Animation Technique on the 7th Grade Science and Technology Course. Journal of Creative Education, 3(3), 304-308. https://doi.org/10.4236/ce.2012.33048

Asmawati, A., \& Dalming, T. (2019). Pengembangan Media Animasi Flash Asam Basa Dengan Metode Hannafin dan Peck. Quantum, 10(2), 104-112.

Asrial, A., Syahrial, S., Kurniawan, D. A., Chan, F., Septianingsih, R., \& Perdana, R. (2019). Multimedia Innovation 4 . 0 in Education: E-Modul Ethnoconstructivism. Universal Journal of Educational Research, 7(10), 2098-2107. https://doi.org/10.13189/ujer.2019.071 007

Astiningsih, A. D., \& Partana, C. F. (2020). Using Android Media for Chemistry Learning Construction of Motivation and Metacognition Ability. International Journal of Instruction, 13(1), 279-294.

Badlisyah, T., \& Maghfirah, M. (2017). Penggunaan Macromedia Flash Pada Materi Larutan Penyangga Terhadap Hasil Belajar Siswa Kelas XI MAN Darussalam. Lantanida Journal, 5(1).

Castro, C., \& Andrade, A. (2011). Teaching Chemistry in a Social Learning Environment: Facing Drivers and Barriers. Proceeding of ICERI, (November), 3377-3385.

Christianti, S., \& Subroto, T. (2012). Model Pembelajaran Guided Note Taking Berbantuan Media ChemoEdutainment pada Materi Pokok Koloid. Jurnal Pendidikan IPA Indonesia (JPII), 1(1), 27-31.

Eliyarti, E., \& Rahayu, C. (2019a). Deskripsi Efektivitas Kegiatan Praktikum Dalam Perkuliahan Kimia Dasar Mahasiswa Teknik. Edu Sains : Jurnal Pendidikan Sains \& Matematika, 7(2), 51-60. 
Technology Research (IJSTR), 9(03), 1051-1056.

Motivasi Berprestasi Mahasiswa

Teknik Dalam Perkuliahan Kimia

Dasar. Jurnal Pendidikan Glasser, 3(2), 196-204.

Eliyarti, E., Rahayu, C., \& Zakirman, Z. (2020). Tinjauan Kontribusi Google Classroom Dalam Mendukung Perkuliahan Kimia Dasar. Jurnal Pendidikan Kimia Indonesia, 4(1), 3239.

Epinur, E., \& Yusnidar, Y. (2015). Pengembangan Laboratorium Virtual Dengan Macromedia Flash 8 Materi Larutan Asam-Basa Untuk Kimia Dasar II. Journal of The Indonesian Society of Integrated Chemistry, 7(2), $1-11$.

Ezeano, A., \& Ezeudu, F. (2013). Application of Laboratory Management Skills by Chemistry Teachers in Enugu State. Journal of Education and Practice, 4(18), 159165.

Febliza, A., \& Afdal, Z. (2019). Pemanfaatan Animasi Macromedia Flash Dalam Meningkatkan Hasil Belajar calon Guru. Journal of Research and Education Chemistry (JREC), 1(2), 18.

Gusbandono, T., Sukadrjo, J., \& Utomo, S. B. (2013). Pengaruh Metode Pembelajaran Kooperatif Student Team Achievement Division (STAD) Dilengkapi Media Animasi Macromedia Flash dan Plastisin Terhadap Prestasi Belajar Siswa Pada Pokok Bahasan Ikatan Kimia Kelas X Semester 1 SMA Negeri 1 Sambungmacan Tahun Pel. Jurnal Pendidikan Kimia (JPK), 2(4), 102109.

Gusta, W., Christina, D., \& Zakirman, Z. (2020). Improved Student Collaboration Skills On English Learning Using Jigsaw Models. International Journal of Scientific \&
Hartiti, R. (2013). Penerapan Media Animasi Flash Dalam Pembelajaran Motif Batik Siswa Kelas X SMA Negeri 1 Menganti. Jurnal Pendidikan Seni Rupa, 1(1), 47-55.

Haryani, M. E., \& Edi, R. (2019). Pengembangan Bahan Ajar Berbasis Multimedia Pada Pembelajaran Kimia Dasar FKIP Universitas Sriwijaya. Jurnal Penelitian Pendidikan Kimia: Kajian Hasil Penelitian Pendidikan Kimia, 6(1), 34-40.

Kittidachanupap, N., Singthongchai, J., \& Naenudorn, E. (2012). Development of animation media for learning English vocabulary for children. International Conference of Electronicals Learning, (May). https://doi.org/10.1109/CSAE.2012.62 72788

Manurung, H. M. (2021). Model Pembelajaran Kimia Kreatif Berbasis $P B L \quad$ Menggunakan Macromedia Flash. Bandung: Widina Bhakti Persada Bandung.

Nurdin, F., Sulastry, T., \& Hasri, H. (2018). Pengaruh Penggunaan Media Pembelajaran Berbasis Macromedia Flash 8 Pada Model Pembelajaran Kooperatif Melalui Pendekatan Saintifik Terhadap Motivasi dan Hasil Belajar (Study Pada Materi Pokok Laju Reaksi). Chemistry Education Review, 1(2), 29-43.

Nurseto, T. (2011). Membuat Media Pembelajaran yang Menarik. Jurnal Ekonomi \& Pendidikan, 8(1), 19-35.

O.I, I., \& N.N.C, S. (2017). Effect of Computer Animation on Chemistry Academic Achievement of Secondary School Students in Anambra State, Nigeria. Journal of Emerging Trends in Educational Research and Policy Studies (JETERAPS), 8(2), 98-102. 
Purwanto, N. (2010). Prinsip-Prinsip dan Teknik Evaluasi Pengajaran. Jakarta: Rosda.

Putri, S. D., Ulhusna, M., Zakirman, Z., \& Gusta, W. (2020). Improvement of Student Science Literacy Skills Through Edmodo- Based Teaching Materials in Learning Science in Elementary School. International Journal of Scientific \& Technology Research (IJSTR), 9(03), 4649-4652.

Rahayu, C., \& Eliyarti, E. (2019). Implementation of Physics Learning Materials Based Generative Learning With Open-Ended Problem Approach To Stimulate Critical Thinking Skills. JIPF (Jurnal IImu Pendidikan Fisika), 4(2), 99. https://doi.org/10.26737/jipf.v4i2.1096

Satriaji, ari kunto. (2018). Implementasi Media Animasi Macroedia Flash Dalam Pembelajaran Keterampilan Berbicara Bahasa Jerman. Jurnal Pendidikan Bahasa Jerman, 1-10.

Sormin, E., \& Daeli, R. (2018). Pengembangan Macromedia Flash Dalam Pembelajaran Kimia Pada Materi Ikatan Kimia Untuk Meningkatkan Minat Belajar Siswa. Jurnal EduMatSains, 2(2), 115-130.

Sugiharti, G., \& Ananda, W. R. (2021). The Effect of Instruction Model Using Media and Motivation on Chemical Learning Results ( Study of The Effect of Instruction Models Using Media and Motivation in Learning ). Journal of Physics: Conference Series, 1940, 17. https://doi.org/10.1088/17426596/1940/1/012116

Sumarni, W., Sudarmin, S., \& Kadarwati, S. (2013). Pembelajaran Berbasis Multimedia Untuk Meningkatkan Penguasaan Konsep Kimia dan Keterampilan Berpikir Mahasiswa. Jurnal Ilmu Pendidikan, 19(1), 69-77.

Wiwit, A. H., \& Putra, D. D. (2012).
Penerapan Model Pembelajaran Kooperatif Tipe TGT dengan dan Tanpa Penggunaan Media Animasi terhadap Hasil Belajar Kimia Siswa SMA Negeri 9 Kota Bengkulu. Jurnal Exacta, $X(1), 71-78$.

Zakirman, \& Rahayu, C. (2018). Popularitas WhatsApp Sebagai Media Komunikasi dan Berbagi Informasi Akademik Mahasiswa. Perpustakaan Arsip Dan Dokumentasi, 10(1), 27-38. https://doi.org/10.15548/shaut.v10i1.7

Zakirman, Z. (2017). Pengelompokan Gaya Belajar Mahasiswa Menurut Teori Honey Mumford Berdasarkan Intensitas Kunjungan Pustaka. RISTEKDIK; Jurnal Bimbingan Dan Konseling, 4(1), 1-6.

Zakirman, Z. (2019). Peningkatan Minat Baca Siswa Melalui Penerapan Model Pembelajaran Play-Think-Pair-Share di SDN 19 Nan Sabaris. Shaut AlMaktabah: Jurnal Perpustakaan, Arsip Dan Dokumentasi, 11(1), 41-51. https://doi.org/10.15548/shaut.v11i1.1 62

Zakirman, Z., Lufri, L., Khairani, K., \& Rahayu, C. (2020). Implementation of The Play-Think-Pair-Share (PTPS) Learning Model for Elementary School Students to Master Part of Top Skill 2020. International Journal of Scientific \& Technology Research (IJSTR), 9(03), 4643-4648.

Zulfiani, Z., Suwarna, I. P., \& Miranto, S. (2010). Science Education Adaptive Computer-Based Science Learning With Learning Style Variations. Journal of Baltic Science Education, 17(4), 711-728. 